\title{
Volatility Due to Offshoring: Theory and Evidence
}

\author{
Paul R. Bergin \\ University of California, Davis, and NBER \\ Robert C. Feenstra \\ University of California, Davis, and NBER \\ Gordon H. Hanson \\ University of California, San Diego, and NBER
}

This draft: January 7, 2011

\begin{abstract}
:
Existing models of offshoring are not equipped to explain how global production sharing affects the volatility of economic activity. This paper develops a trade model that can account for why offshoring industries in low wage countries such as Mexico experience fluctuations in employment that are twice as large as in high wage countries such as the United States. We argue that a key to explaining this outcome is that the extensive margin of offshoring responds endogenously to shocks in demand and transmits those shocks across borders in an amplified manner. Empirical evidence supports the claim that the extensive margin of offshoring is an active margin of adjustment, and quantitative simulation experiments show that the degree of movement of this margin in the data is sufficient to explain relative employment volatility in Mexico and the U.S.
\end{abstract}

JEL classification: F1, F4

Keywords: Offshoring, outsourcing, employment, volatility, maquiladoras

\footnotetext{
Corresponding author: P. Bergin / Department of Economics / University of California at Davis/ One Shields Ave. / Davis, CA 95616 USA prbergin@ucdavis.edu, ph (730) 752-0741, fax (730) 752-9382.

G. Hanson / University of California, San Diego / 9500 Gilman Dr., MC: 0519 La Jolla, CA 92093-0519 USA, gohanson@ucsd.edu, ph (1058) 822-5087, fax (1058) 534-3939.

R. Feenstra / Department of Economics / University of California at Davis/ One Shields Ave. / Davis, CA 95616 USA rcfeenstra@ucdavis.edu, ph (730) 752-7022, fax (730) 752-9382.
} 


\section{Introduction}

International trade is being transformed by offshoring, the arrangement whereby firms contract to carry out particular stages of production abroad. U.S., European, and Japanese firms that conduct product design and the production of sophisticated components at home use factories in Asia, Eastern Europe, and Latin America to assemble inputs into final outputs for delivery to consumers. Offshoring is especially common in apparel, auto parts, electronics, and machinery, which are industries whose production stages are physically separable (such that they can be performed in different locations) and differ sharply in their factor intensities (such that fragmenting production across borders is attractive). A substantial portion of the recent growth in global trade is tied to offshoring (Hummels, Ishii, and Yi, 2001). The literature on global production sharing is expanding rapidly, with recent work examining which firms choose to engage in offshoring (Antras and Helpman, 2004), how global production sharing affects the relative demand for skilled labor (Feenstra and Hanson, 1999; Ebenstein, Harrison, McMillan, and Phillips, 2010) and the productivity of domestic factors (Grossman and Rossi-Hansberg, 2008), and the expansion of offshoring into services (Amiti and Wei, 2006). ${ }^{1}$

One consequence of global production sharing that has received relatively little attention is the effect of offshoring on the volatility of production. As U.S. firms have expanded the number of export assembly plants in Mexico, for instance, Mexican industry has become more tied to the U.S. economy. This outcome is consistent with Burstein, Kurz and Tesar (2008), who develop a real business cycle model in which global production sharing leads trading economies to have more synchronized business cycles. ${ }^{2}$ A distinct and important feature of offshoring is excess volatility in the low-wage trading partner. Mexico’s maquiladoras, as its assembly plants are known, exhibit

\footnotetext{
${ }^{1}$ The papers listed are a subset of a much larger body of work. See Feenstra (2009) for a discussion of the literature.

${ }^{2}$ In related work, Zlate (2008) develops a dynamic model to study the effects of offshoring on international business cycle correlations and real exchange rate dynamics. Other work on intermediate inputs and business cycle synchronization include Kose and Yi (2001, 2006) and Ambler, Cardia, and Zimmerman (2002).
} 
swings in activity that are more exaggerated than in the United States. ${ }^{3}$ Employment in Mexican maquiladoras that produce auto parts declined by $13.8 \%$ in the 2001 recession, after expanding by 88.4\% in the 1991-2001 expansion. U.S. employment in auto parts, in contrast, contracted by only 9.9\% in 2001, after 33.9\% growth from 1991 to 2001. Bergin, Feenstra, and Hanson (2009) document that maquiladora industries in Mexico associated with U.S. offshoring have fluctuations in employment that are twice as volatile as the corresponding industries in the U.S., a finding based on matching Mexico’s four largest offshoring industries (apparel, transportation equipment, computers and electronics, and electrical machinery) to their U.S. counterparts at the three digit level. ${ }^{4}$ The pattern of greater relative volatility in Mexico appears to be present also in the most recent recession starting in late 2007. Comin et al. (2009) document that while the Mexican recession started subsequently to that in the U.S., it was significantly more severe, with a drop in output more than three times that in the U.S.

Why would outsourcing industries in Mexico have higher volatility than their U.S. counterparts? One conjecture is that high volatility in Mexican maquiladoras simply reflects higher volatility in the Mexican economy overall. However, employment volatility for aggregate manufacturing in Mexico is actually lower than in the U.S. (Bergin, Feenstra, and Hanson, 2009). A second conjecture is that labor-market institutions differ between the countries, such that it is easier

\footnotetext{
${ }^{3}$ We measure U.S. production sharing in Mexico using data on maquiladoras. These export assembly plants capture a large share of U.S. offshoring to Mexico. However, Burstein, Kurz, and Tesar (2008), using BEA data on the foreign-owned affiliates of U.S. multinationals, document that U.S. offshoring to Mexico involves non-maquiladora establishments, as well. U.S. firms license technology, subcontract production, and share distribution networks with a range of Mexican businesses. Three features make the maquiladora data, rather than BEA multinational data or other sources, suitable for our purposes. First, as Burstein, Kurz, and Tesar show, the intensity of production sharing (measured as the share of exports to the U.S. in establishment total sales) is much higher in maquiladoras (90\%) than in non-maquiladoras (21\%). Second, whereas BEA data are limited to affiliates in Mexico owned by U.S. multinationals, our maquiladora data include both U.S. owned affiliates and arms-length suppliers to U.S. firms. Third, maquiladora data are available at a monthly frequency, permitting us to examine the business cycle characteristics of offshoring, whereas BEA data are available only every five years.

${ }^{4}$ The next two largest industries in terms of maquiladora employment in Mexico are miscellaneous industries (11.3\% of employment) and furniture (4.9\% of employment). We exclude miscellaneous industries because we cannot match them to specific U.S. sectors (miscellaneous industries in Mexico are distinct from those in the U.S.) and furniture, owing to inconsistencies in the data series for the industry in Mexico. Other manufacturing industries (chemicals, toys, tools, food, and footwear) collectively account for just $6.2 \%$ of maquiladora employment.
} 
to hire and fire employees in Mexico. Yet, when Botero et al. (2004) rank countries in terms of job security laws restricting the hiring and firing of workers, Mexico ties for the most regulated among the 85 countries in the sample, whereas the U.S. ranks as the fifth least regulated economy, a finding consistent with Mexico having lower aggregate employment volatility. ${ }^{5}$

In this paper, we offer an explanation for the offshoring-employment volatility puzzle by developing a model of global production sharing in which the decisions of firms respond to macroeconomic shocks. The offshoring sector consists of a continuum of products with heterogeneous unit labor requirements, along the lines of Dornbusch-Fisher-Samuelson (1977) and Eaton-Kortum (2002). This sector is embedded in a two country, general equilibrium macroeconomic model, which also includes a homogeneous traded good in each country. Labor supply is endogenous and the wages of each country are determined in a general equilibrium that is affected by shocks to aggregate demand and supply. The model is stochastic and results for second moments are derived in a calibrated simulation exercise.

A key feature of the model is that the point along the product continuum at which firms in the home country begin to offshore production to the foreign country is endogenously determined as firms compare unit-labor costs across borders. When the home country has a boom in demand, the fact that home wages tend to be procyclical alters the offshoring decision of some firms. ${ }^{6}$ Since home workers become relatively more expensive to hire, firms that previously had not offshored any production now find it profitable to do so. This shift in the extensive margin acts as a powerful mechanism for the international transmission of shocks, whereby U.S. producers shift

\footnotetext{
${ }^{5}$ The labor regulations evaluated by Botero et al. (2004) apply to the formal sector in the countries considered. In Mexico, there is substantial employment (largely in services) in the informal sector, in which the enforcement of labor laws is relatively lax. The data we use on maquiladoras are limited to plants in the formal sector and the data we use on aggregate Mexican manufacturing are limited to plants with more than 15 employees (which account for over 80 percent of total sales in manufacturing), the large majority of which are in the formal sector (see http://www.inegi.org.mx/prod_serv/contenidos/espanol/bvinegi/productos/encuestas/establecimientos/eim/mensual/e im.pdf). While there is employment in Mexico subject to lax labor regulation, it is largely absent in our data.

${ }^{6}$ Huang et al. (2004) survey recent evidence confirming procyclicality of wages in the U.S. in the postwar period, unconditionally as well as conditional on demand shocks.
} 
disproportionately high levels of production abroad during a domestic economic boom, and the reverse during a recession. Numerical examples, by way of stochastic simulation under demand and supply shocks, indicate that the mechanism provides a potential explanation for the extra volatility in Mexican offshoring, relative to the U.S. Even when the shock is a purely domestic one (e.g., specific to the U.S.), it is amplified in its transmission abroad, such that it has a greater impact on the offshoring industries in the low-wage foreign country than on the domestic counterpart industries.

There are two reasons why in our model shocks to home demand are amplified in their effect abroad. First, the foreign offshoring sector (e.g., maquiladoras in Mexico) has smaller total employment than in the home country (e.g., the U.S.). Any given shift in an absolute amount of employment therefore has an amplified effect on foreign volatility. Second, because procyclical domestic wages induce more offshoring during domestic demand booms, the rise in domestic employment due to the boom and the fall in domestic employment due to greater offshoring counteract each other. In contrast, the foreign country experiences the effect of offshoring unmitigated by a counteracting effect. Because production in Mexican Maquiladoras is substantially directed toward U.S. demand, a prominent role for U.S. demand shocks gives this mechanism potency for Mexican offshoring employment.

To examine a key implication of the theory for the offshoring margin, we collect data on Mexican exports at U.S. ports of entry associated with offshoring, which record both the value of exports and the number of product classifications exported. We find that at a monthly frequency there are substantial changes in the extensive margin of offshoring, consistent with our theory. Further, the degree of volatility of this margin observed in the data matches well the degree of volatility implied by the calibrated theoretical model, and it is quantitatively sufficient to explain the volatility puzzle in employment data.

The next two sections present the theoretical model and analytical results. Simulation results follow in section 4 . Section 5 presents empirical support, followed by a concluding summary. 


\section{Theoretical Model}

We embed a model of offshoring in a simple dynamic stochastic general equilibrium model of two countries. Label the two countries as home and foreign, with foreign variables denoted by an asterisk. The offshoring relationship involves the home country offshoring to the foreign country, so that home may be thought of as representing the U.S. and foreign as representing Mexico. We will scale the quantity variables coming from the foreign country by its relative size: if the share $n$ of the world population resides at home and 1- $n$ in the foreign country, then we scale foreign quantities by $(1-n) / n$

\subsection{Pricing and Product Variety in the Offshoring Sector}

Each country has two sectors. The first is a standard homogeneous good whose production is specific to that country; this country-specific sector will be subscripted by $H$ for the home produced good and $F$ for the foreign produced good. The second sector consists of differentiated products that are multinational, subscripted by $M$, in that they can be produced using factors in either country. This sector will be referred to as the offshoring sector. There is a continuum of products in this sector indexed by $z \in[0,1] .^{7}$

Production in the offshoring sector involves a unit labor input requirement that differs by product. To characterize the distribution of the relative unit-labor requirement function between countries, we follow Eaton and Kortum (2002, footnote 15), who develop a Ricardian model of trade in which firms randomly draw their productivities and countries differ in their average sectoral efficiency level. In a two country context their model implies a function for the relative unit labor requirement resembling that of Dornbusch, Fisher and Samuelson (1977),

\footnotetext{
${ }^{7}$ See the working paper version Bergin, Feenstra Hanson (2007) for an expanded version of the model with free entry of firms into each industry.
} 


$$
A(z)=\frac{a_{M t}(z)}{a_{M t}^{*}(z)}=\left(\frac{T}{T^{*}}\right)^{\frac{1}{\theta}}\left(\frac{1-z}{Z}\right)^{\frac{1}{\theta}} \cdot 8
$$

In the formulation used here, $T$ and $T^{*}$ scale the unit labor requirement levels of the home and foreign country respectively, and $\theta$ characterizes the curvature of the distribution of productivities. By ordering of the products $z$, we assume that $A(z)$ is decreasing in $z$, i.e. products are arranged by increasing order of home comparative advantage. It follows that those offshoring activities below some cutoff $z_{t}{ }_{t}$ will be produced in the foreign country, while those activities above $z_{t}{ }_{t}$ will be done at home. The cutoff activity $Z_{t}{ }_{t}$ is determined by the equality of unit-labor costs in the two countries, or given the wages $W_{t}$ and $W_{t}^{*}$, by: ${ }^{9}$

$$
A\left(Z^{\prime}{ }_{t}\right)=\frac{W_{t}^{*}}{W_{t}}
$$

Overall home demand in this multinational sector is specified as,

$$
\ln D_{M t}=\int_{0}^{1} \ln d_{M t}(z) d z
$$

where $d_{M t}(z)$ is the demand for a product $z$. The market for each $z$ is assumed to be perfectly competitive. The composite multinational good $D_{M t}$ will serve as the numeraire. The price index of multinational goods is computed by integrating over the distribution of unit costs in each country over the relevant range, where we split the relative unit cost distribution (1) into a home and foreign

\footnotetext{
${ }^{8}$ Footnote 15 of Eaton and Kortum (2002) derives the following function $A(x)$, where $x$ is the fraction of goods for which the ratio of home (country 1 ) to foreign (country 2) efficiency is at least $A: A(x)=\left(T_{1} / T_{2}\right)^{\frac{1}{\theta}}((1-x) / x)^{\frac{1}{\theta}}$. Our distribution, $A(z)$ is a direct transformation of this function in terms of relative unit labor costs, where $z$ is the fraction of goods for which the ratio of home to foreign unit labor cost is less than $A$. In this transformation, the heterogeneity parameter $\theta$ is exactly the same as in Eaton and Kortum (2002, footnote 15), but the efficiency constants are replaced by unit labor cost constants: $T=1 / T_{1}$ and $T^{*}=1 / T_{2}$. ${ }^{9}$ Our model abstracts away from overtime pay, which contributes to the procyclicality of wages (see, e.g., Bils, 1987). Unfortunately, there is scant literature comparing the prevalence of overtime pay in the U.S. and Mexico.
} 
component: $a_{M, t}(z)=\left(\frac{T}{z}\right)^{\frac{1}{\theta}}$ for home, and $a_{M, t}^{*}(z)=\left(\frac{T^{*}}{1-z}\right)^{\frac{1}{\theta}}$ for foreign. The price index for these goods is computed as (see the appendix):

$$
\begin{aligned}
& \ln P_{M t}=\int_{0}^{z_{t}^{\prime}} \ln \left(W_{t}^{*} a_{M, t}^{*}\left(z_{t}\right)\right) d z+\int_{z_{t}^{\prime}}^{1} \ln \left(W_{t} a_{M, t}\left(z_{t}\right)\right) d z \\
& =\ln \left(W_{t}^{*} T^{* \frac{1}{\theta}}\right) Z_{t}^{\prime}+\ln \left(W_{t} T^{\frac{1}{\theta}}\right)\left(1-z_{t}^{\prime}\right)+\frac{1}{\theta}\left(\left(1-z_{t}^{\prime}\right) \ln \left(1-z_{t}^{\prime}\right)\right)-\frac{1}{\theta}\left(z_{t}^{\prime} \ln _{t}{ }_{t}^{\prime}\right)+\frac{2}{\theta} Z_{t}^{\prime}+\frac{1}{\theta}
\end{aligned}
$$

The overall labor demand in the multinational sector at home, $L_{M t}$, consists of labor used for activities not offshored $\left(z_{t}>z_{t}{ }_{t}\right)$; labor demand abroad includes offshored activities $\left(z_{t}<z_{t}{ }_{t}\right)$. The appendix derives these labor demands:

$$
\begin{aligned}
& L_{M t}=\left(\frac{D_{M t}+D_{M t}^{*}\left(\frac{1-n}{n}\right)}{W_{t}}\right)\left(1-Z_{t}^{\prime}\right) \\
& \left(\frac{1-n}{n}\right) L_{M t}^{*}=\left(\frac{D_{M t}+D_{M t}^{*}\left(\frac{1-n}{n}\right)}{W_{t}^{*}}\right) Z_{t}^{\prime} .
\end{aligned}
$$

\subsection{Production in the Rest of the Economy}

The offshoring model is embedded in a general equilibrium setting that is standard in the open macroeconomy literature. The country-specific sector in the home country is a perfectly competitive market for the homogeneous traded good with production function:

$$
Y_{H t}=\frac{L_{H t}}{a_{H t}}
$$

where $L_{H t}$ is labor in the home country-specific sector and $a_{H t}$ is its unit labor input requirement. Prices in a competitive equilibrium are,

$$
p_{H t}=W_{t} a_{H t}
$$


where $p_{H t}$ is the relative price of the home domestic good in terms of the multinational good numeraire. Analogous conditions apply to the foreign country’s homogeneous good.

\subsection{Households}

Household preferences in the home country are represented by an instantaneous utility function of consumption $\left(C_{t}\right)$, which is a Cobb-Douglas composite of goods in the three sectors, and overall labor $\left(L_{t}\right)$ :

$$
\begin{aligned}
& U_{t}=\frac{1}{1-\phi} C_{t}^{1-\phi}-\frac{1}{1+\mu} L_{t}^{1+\mu} \\
& \text { where } \\
& C_{t}=\left(C_{M t}^{\alpha} C_{H t}^{1-\alpha}\right)^{\omega_{t}} C_{F t}^{1-\omega_{t}}
\end{aligned}
$$

$C_{M}$ denotes consumption by home private households of the multinational good, $C_{H}$ home private consumption of the home good, and $C_{F}$ home private consumption of the foreign good. As private consumption is the only form of expenditure in the benchmark version of the model, $C_{M}$ is identical for the time being to overall demand in the $M$ sector, $D_{M}$, defined earlier.

The implications of uncertainty in the model will be dealt with in a simple manner by assuming complete asset markets, as commonly assumed in the international macroeconomic literature (see Chari, et al., 2002). In each period $t$, the economy experiences one of finitely many events, $s_{t}$. We denote by $s^{t}=\left(s_{0}, \cdots, s_{t}\right)$ the history of events up through and including period $t$. All variables referred to so far are implicitly functions of the states of nature in period $t$ (e.g., $Y_{H t} \equiv Y_{H}\left(s^{t}\right)$ ). In period $t$, consumers in either country purchase state-contingent assets in units of the numeraire good, denoted by $B_{t+1} \equiv B\left(s^{t+1}\right)$, which bear a return of exactly one unit of the numeraire good in period $t+1$ if state $s^{t+1}$ occurs. They purchase these assets at the prices $V\left(s^{t+1} \mid s^{t}\right)$, which denotes the price of one unit 
of the numeraire good at $s^{t+1}$ in units of the numeraire good at state $s^{t}$. The budget constraint facing the home household in period $t$ is therefore:

$$
P_{t} C_{t}+\sum_{s^{t+1}} V\left(s^{t+1} \mid s^{t}\right) B\left(s^{t+1}\right)=W_{t} L_{t}+B_{t}
$$

where $P_{t}$ is the price index of the home country consumption basket in terms of the numeraire good.

Labor is mobile between sectors within a country, but there is no labor mobility between countries, meaning each country has a single but distinct equilibrium wage rate.

Households maximize the expected discounted sum of current and future instantaneous utility defined above, using the discount factor $\beta$, subject to the budget constraint. ${ }^{10}$ The first order conditions for this problem imply the following. Risk-sharing equates nominal marginal utilities of consumption apart from a constant of proportionality,

$$
\frac{P_{t} C_{t}^{\phi}}{P^{*}{ }_{t} C_{t}^{* \phi}}=\zeta
$$

where $\zeta$ is a constant indicating the relative per-capita wealth of the home country in the initial asset allocation. Demands for the goods are:

$$
\begin{aligned}
C_{M t} & =\alpha \omega\left(\frac{P_{t}}{P_{M t}}\right) C_{t} \\
C_{H t} & =(1-\alpha) \omega\left(\frac{P_{t}}{P_{H t}}\right) C_{t} \\
\text { and, } \quad C_{F t} & =(1-\omega)\left(\frac{P_{t}}{P_{F t}}\right) C_{t}
\end{aligned}
$$

Labor supply is

$$
L_{t}^{\mu}=\frac{W_{t}}{P_{t}} C_{t}^{-\phi}
$$

\footnotetext{
${ }^{10}$ As the discount factor $\beta$ is assumed identical across countries, it cancels out of the risk sharing condition (16), and does not appear in the other equations of the model.
} 
Corresponding conditions apply for the foreign country.

\subsection{Market Clearing and Equilibrium}

Market clearing in the home goods market requires:

$$
D_{H t}+\left(\frac{1-n}{n}\right) D_{H t}^{*}=Y_{H t}
$$

where $D_{H t}$ and $D_{H t}^{*}$ are home and foreign demands for the home good. Again, because consumption is the only source of demand in the benchmark model, we may substitute $C_{H t}$ for $D_{H t}$ and $\mathrm{C}_{\mathrm{Ht}}^{*}$ for $D_{\mathrm{Ht}}^{*}$. There is an analogous condition for the foreign good.

Equilibrium in the labor market requires that overall labor supply equal the sum of labor demands across sectors:

$$
\begin{aligned}
& L_{t}=L_{H t}+L_{M t}, \\
& L_{t}^{*}=L_{F t}^{*}+L_{M t}^{*} .
\end{aligned}
$$

The general equilibrium is a sequence of 17 endogenous variables: $L_{t}, L_{t}^{*}, L_{H t}, L_{F t}^{*}, L_{M t}, L_{M t}^{*}, W_{t}, W_{t}^{*}$, $C_{H t}, C_{H t}^{*}, C_{F t}, C_{F t}^{*} C_{M t}, C_{M t}^{*}, P_{H t}, P_{F t}$, and $z_{t}^{\prime}$, where we have used the fact $D_{i t}=C_{i t}$ and ${D^{*}}^{*}=C^{*}{ }_{i t}$ for $i=M, H, F$. These variables are determined by the labor-supply condition (14), demand for the multinational and home country-specific goods (11) and (12), labor demand for the country-specific sector (5) and the multinational sector (7), the market clearing condition for the country-specific sector (15), the market clearing condition for labor (16), and the foreign counterparts for each of these. In addition, there is the marginal offshoring condition (2), the risk sharing condition in (10), and the normalization of the price of the numeraire good $P_{M t}=1$.

\section{Analytical Results}


While a closed-form analytical solution is not possible for this model, we can solve for relative country ratios, which is helpful in providing intuition for the main result. Taking the ratio of labor demand conditions for the multinational sector, (5) and (6), and substituting for relative wages using condition (2):

$$
\frac{L_{M t}^{*}}{L_{M t}}=\left(\frac{Z_{t}^{\prime}}{1-Z_{t}^{\prime}}\right)^{1+\frac{1}{\theta}}\left(\frac{T^{*}}{T}\right)^{\frac{1}{\theta}}\left(\frac{n}{1-n}\right) .
$$

This condition makes clear that if the offshoring margin, $z$, were not endogenous but instead assumed to be fixed, then the labor demands in the offshoring sectors of the two countries would be exactly proportional to each other. Since all other terms in the expression are constants, the standard deviations in log terms of offshoring employment in each country would be identical, $\sigma\left(L_{M t}^{*}\right)=\sigma\left(L_{M t}\right)$, and it would be impossible to replicate the stylized fact of higher volatility in Mexican offshoring employment. This result points to the essential role played by an endogenous offshoring margin in explaining the volatility puzzle. The shock considered initially will be a demand shock in the form of a rise in the preference parameter $\omega_{t}$, which increases demand for home and multinational goods relative to foreign goods. Let deviations of $\omega_{t}$ from its mean follow an iid lognormally distributed process. Assume that the foreign household has identical preferences.

Given the important role of endogenous changes in the offshoring margin, we solve for the equilibrium response of z' to the exogenous shock to demand $\omega_{t}$. To solve the model, we start with the relative wage, which equates the ratio of total labor demands in the overall economies to the ratio of their labor supplies. Begin with total home labor demand, using the production function (7) and goods market clearing (15) for labor demand in the home goods sector, $L_{H t}$ 


$$
L_{t}=L_{M t}+L_{H t}=\left(\frac{C_{M t}+C_{M t}^{*}\left(\frac{1-n}{n}\right)}{W_{t}}\right)\left(1-Z_{t}^{\prime}\right)+a_{H}\left(C_{H t}+C_{H t}^{*}\left(\frac{1-n}{n}\right)\right)
$$

Use demand conditions (11) and (12), along with price setting for the home good and the normalization for the price of the multinational good, and do likewise for the foreign country:

$$
L_{t}=\omega_{t}\left(1-\alpha z_{t}{ }_{t}\right) P_{t}\left(\frac{C_{t}+C_{t}^{*}\left(\frac{1-n}{n}\right)}{W_{t}}\right) \text { and } L_{t}^{*}=L_{M t}^{*}+L_{F t}^{*}=\left(\alpha \omega_{t} z_{t}{ }_{t}+\left(1-\omega_{t}\right)\right) P_{t}\left(\frac{C_{t}+C_{t}^{*}\left(\frac{1-n}{n}\right)}{W_{t}^{*}}\right)\left(\frac{n}{1-n}\right)
$$

Set the cross-country ratio of these labor demands equal to the ratio of labor supplies from condition (14):

$$
\left(\frac{\frac{W^{*}{ }_{t}^{*}}{P_{t}^{*}} C_{t}^{*-\phi}}{\frac{W_{t}}{P_{t}} C_{t}^{-\phi}}\right)^{\frac{1}{\mu}}=\frac{L_{t}^{*}}{L_{t}}=\left(\frac{W_{t}}{W^{*}{ }_{t}}\right) \frac{\alpha \omega_{t} Z_{t}{ }_{t}+\left(1-\omega_{t}\right)}{\omega_{t}\left(1-\alpha Z^{\prime}{ }_{t}\right)}\left(\frac{n}{1-n}\right)
$$

Use the complete asset markets condition (10), along with the technology distribution (1) and marginal offshoring condition (2):

$$
(\zeta)^{\frac{1}{\mu}}\left(\frac{T}{T^{*}}\right)^{\frac{1}{\theta}\left(1+\frac{1}{\mu}\right)}\left(\frac{1-n}{n}\right)=\left(\frac{Z_{t}^{\prime}}{1-Z_{t}^{\prime}}\right)^{\frac{1}{\theta}\left(1+\frac{1}{\mu}\right)}\left(\frac{\alpha \omega_{t} Z_{t}^{\prime}+\left(1-\omega_{t}\right)}{\omega_{t}\left(1-\alpha Z_{t}^{\prime}\right)}\right)=0 .
$$

This is an implicit function for $z_{t}^{\prime}$ as a function of the preference and technology parameters.

Let us consider the effects of a demand shock that takes the form of a rise in the share of consumption expenditure allocated to home and multinational goods and away from foreign goods, a rise in $\omega_{t}$. We can find the comparative static effect on the offshoring margin, $z_{t}^{\prime}$, as follows. By differentiating over the implicit function above, labeled as $F=0$, it is easy to verify that $\frac{d z_{t}^{\prime}}{d \omega_{t}}=-\frac{d F}{d \omega_{t}} / \frac{d F}{d z_{t}^{\prime}}>0$ (see the appendix for the derivation). A rise in demand $\omega_{t}$ leads to an increase 
in the margin of offshoring. Combined with the marginal offshoring condition (2), this immediately implies a rise in the relative home wage, $W_{t} / W_{t} *$. And equation (19) implies a rise in relative home total employment, $L_{t} / L_{t}{ }^{*}$. Together, these results imply the following story: a demand shock biased toward home goods raises relative demand for home labor and hence raises home relative wages. This induces firms to offshore a greater range of goods in the offshoring sector to the foreign country.

Returning to equation (18), the systematic movement in the offshoring margin has implications for the relative volatilities in employment in the two countries' offshoring sectors. Taking natural logs of (18) and differentiating with respect to the demand shock $\omega_{t}$

$$
\frac{d \ln L_{M t}^{*}}{d \omega_{t}}=\frac{d \ln L_{M t}}{d \omega_{t}}+\left(1+\frac{1}{\theta}\right) \frac{1}{\left(1-z_{t}^{\prime}\right)} \frac{d \ln z_{t}^{\prime}}{d \omega_{t}} .
$$

Variances can be computed for a log linear approximation around the mean values of $\overline{z^{\prime}}$ :

$$
\operatorname{var}\left(\ln L_{M t}^{*}\right)=\operatorname{var}\left(\ln L_{M t}\right)+\left(1+\frac{1}{\theta}\right)^{2}\left(\frac{1}{1-\bar{Z}^{\prime}}\right)^{2} \operatorname{var}\left(\ln z_{t}^{\prime}\right)+2\left(1+\frac{1}{\theta}\right)\left(\frac{1}{1-\overline{Z^{\prime}}}\right) \operatorname{cov}\left(\ln L_{M t}, \ln z_{t}^{\prime}\right)
$$

As shown in the appendix, this may be rewritten as

$$
\operatorname{var}\left(\ln L_{M t}^{*}\right)=\operatorname{var}\left(\ln L_{M t}\right)+2\left(1+\frac{1}{\theta}\right)\left(\frac{1}{1-\overline{z^{\prime}}}\right) \operatorname{cov}\left(\ln L_{M t}+\ln L_{M t}^{*}, \ln Z_{t}^{\prime}\right)
$$

Thus, a necessary and sufficient condition to have $\operatorname{var}\left(\ln L_{M t}^{*}\right)>\operatorname{var}\left(\ln L_{M t}\right)$ is that

$$
\operatorname{cov}\left(\ln L_{M t}+\ln L_{M t}^{*}, \ln z_{t}^{\prime}\right)>0
$$

There are two effects that can be seen at work. First, for a given share of offshoring, a rise in demand for multinational goods forces an equal percentage rise in employment in this sector in both countries. Second, since the rise in demand coincides with a rise in the share $z_{t}^{\prime}$ of goods offshored, there is a further effect raising employment abroad, but a negative effect counteracting the rise in employment in this sector at home. On net, foreign offshoring employment rises more than at home, 
implying greater foreign volatility in the face of such home demand shocks. Is it in fact the case that $\operatorname{cov}\left(\ln L_{M t}+\ln L_{M t}^{*}, \ln z_{t}^{\prime}\right)>0$ ? The simulation section below will verify that this condition is satisfied in our calibrated model, and the following empirical section will verify that this positive correlation is satisfied in U.S. and Mexican data.

Equation (21) also reveals that relative foreign volatility is higher the smaller is the mean level of the offshoring margin, $\bar{z}^{\prime}$. The relative size of the two countries in the offshoring sector matters because when a movement in the margin shifts an industry from the U.S. to Mexico there is a larger percentage change in Mexico than in the U.S. sector. Note, however, that relative country size in terms of overall population, $n$, cancels out from the above expression when taking log changes. It is size specifically in the offshoring sector that matters for the volatility puzzle.

\section{Numerical Experiment}

\subsection{Model Calibration}

To conduct a quantitative experiment, we calibrate the parameters to represent the U.S. and Mexican economies. To permit calibration of demand shocks to data, these must be reinterpreted somewhat. Recall that the analytical results considered a shock to the home bias parameter, $\omega$, raising the share of demand allocated to home and multinational goods relative to foreign goods. For a quantitative experiment it is not entirely clear what shock in the data such a preference shift would correspond to or how we would calibrate it. The calibrated model instead will study the effect of an equivalent additive shock to government demand, for which data are available. Denoted $G$ and $G^{*}$, government expenditure is allocated among the goods using the same demands as the private consumption as in equations (11)-(12), except that it is assumed that government has complete bias 
toward home goods: $\omega_{G}=\omega_{G}^{*}=1$ for government preferences. ${ }^{11}$ In addition to reflecting the stylized fact of greater home bias in government spending data, this specification allows government spending shocks to resemble the taste shocks assumed in the analytical results. Because government home bias is greater than private home bias $\left(\omega_{G}>\omega\right)$, a shock raising the role of government demand in overall U.S. demand will raise the share of overall home demand allocated to home and multinational goods rather than foreign goods, similar in spirit to the analytical result. The definitions of demands used previously must be expanded to account for government demand along with consumer demand: $D_{M t}=C_{M t}+G_{M t}, D_{H t}=C_{H t}+G_{H t}$, and $D_{F t}^{*}=C_{F t}^{*}+G_{F t}^{*}$.

To deal with aggregate output fluctuations, the model will allow for supply shocks to the technology in the production functions: $a_{H t}$ and $a_{F t}^{*}$. We do not compute a separate set of Solow residuals for the offshoring sector of each country, as this might replicate the higher volatility in the Mexican offshoring sector in a purely mechanical way. Instead, we consider two cases of how a country's domestic technology shocks affect the offshoring sector. One case simply assumes that unit labor requirement moves proportionately in the domestic and offshoring sectors within each country: $\tilde{a}_{M t}\left(\bar{z}^{\prime}\right)=\tilde{a}_{H t}, \tilde{a}_{M t}^{*}\left(\bar{z}^{\prime}\right)=\tilde{a}_{F t}^{*}$, where tildes indicate log deviations from means. This specification implies that the relative cost schedule $A(z)$ shifts in response to technology shocks. The other case differs in that it holds the $A(z)$ schedule fixed, assuming that technology shocks in a country's offshoring sector are perfectly transmitted to the other country’s offshoring sector: $\tilde{a}_{M t}\left(\bar{z}^{\prime}\right)=\tilde{a}_{M t}^{*}\left(\bar{z}^{\prime}\right)=\tilde{a}_{H t}+\tilde{a}_{F t}^{*}$. Such a specification is similar to that assumed in Burstein et al. (2008), and is also consistent with Berman, Bound and Machin (1998) who argue that technology shocks spread quickly to other countries. We take this second specification as our benchmark, although we shall report results for the first case as well.

\footnotetext{
${ }^{11}$ This implies the following particular government demands: $G_{H t}=(1-\alpha)\left(P_{t} / P_{H t}\right) G_{t}, \quad G_{M t}=\alpha\left(P_{t} / P_{M t}\right) G_{t}$, $G_{F, t}^{*}=\left(P_{t}^{*} / P_{F t}^{*}\right) G_{t}$, and $G_{F}=G_{H}^{*}=G_{M}^{*}=0$.
} 
Both demand and supply shocks are specified as first order autoregressions in log deviations from their respective means:

$$
\left[\begin{array}{l}
\log \left(a_{H t}\right)-\log \left(\overline{a_{H}}\right) \\
\log \left(a_{F t}^{*}\right)-\log \left(\overline{a_{F}^{*}}\right)
\end{array}\right]=\rho_{a}\left[\begin{array}{l}
\log \left(a_{H t-1}\right)-\log \left(\overline{a_{H}}\right) \\
\log \left(a_{F t-1}^{*}\right)-\log \left(\overline{a_{F}^{*}}\right)
\end{array}\right]+\left[\begin{array}{c}
\varepsilon_{a H t} \\
\varepsilon_{a F t}
\end{array}\right] \text {, where }\left[\begin{array}{l}
\varepsilon_{a H t} \\
\varepsilon_{a F t}
\end{array}\right] \sim \mathrm{N}\left(\left[\begin{array}{l}
0 \\
0
\end{array}\right], \sigma_{a}^{2}\right)
$$

and: $\quad\left[\begin{array}{c}\log \left(G_{t}\right)-\log (\bar{G}) \\ \log \left(G_{t}^{*}\right)-\log \left(\overline{G^{*}}\right)\end{array}\right]=\rho_{G}\left[\begin{array}{c}\log \left(G_{t-1}\right)-\log (\bar{G}) \\ \log \left(G_{t-1}^{*}\right)-\log \left(\overline{G^{*}}\right)\end{array}\right]+\left[\begin{array}{c}\varepsilon_{G t} \\ \varepsilon_{G^{* t}}\end{array}\right]$, where $\left[\begin{array}{c}\varepsilon_{G t} \\ \varepsilon_{G^{*} t}\end{array}\right] \sim \mathrm{N}\left(\left[\begin{array}{l}0 \\ 0\end{array}\right], \sigma_{G}^{2}\right)$.

Model parameters are calibrated to monthly data for the U.S. and Mexico, and values are summarized in Table 1. To calibrate the steady state level of the offshoring share, the ratio of (6) and (5) indicates that $\bar{z}^{\prime}$ can be calibrated to match the Mexican share of production labor earnings in the offshoring sector.

$$
\frac{(1-n) W_{t}^{*} L_{M t}^{*}}{n W_{t} L_{M t}}=\frac{z_{t}^{\prime}}{1-z_{t}^{\prime}}
$$

Averaging over our data for earnings in the four offshoring industries at the end of our sample indicates a share of 0.06 .

Calibrating the relative unit labor requirement distribution $A(z)$ involves three parameters. The curvature parameter $\theta$ is calibrated at 8.28 based upon the estimation by Eaton and Kortum (2002). ${ }^{12}$ The level parameter for technology in the U.S. offshoring sector, $T$, is calibrated so that the unit labor requirement at the steady state margin in this sector is the same as the unit labor requirement in the domestic goods sector: $a_{M, t}\left(\bar{Z}^{\prime}\right)=\left(\frac{T}{\bar{Z}^{\prime}}\right)^{\frac{1}{\theta}}=\bar{a}_{H, t}=1$, so $T^{1 / \theta}=\bar{Z}^{1 / \theta}=0.712$. Finally, the foreign technology level in the offshoring sector, $T^{*}$, is calibrated so that the relative unit labor requirement,

\footnotetext{
${ }^{12}$ Their estimates are based upon bilateral import shares and price differences for 50 manufactured products, most of which coincide with offshoring industries.
} 
which determines the relative wage across countries, equals the relative wage in our data set, which is 1/8: $A\left(z^{\prime}\right)=\left(\frac{T}{T^{*}}\right)^{\frac{1}{\theta}}\left(\frac{1-z^{\prime}}{z^{\prime}}\right)^{\frac{1}{\theta}}=\frac{\bar{W}^{*}}{\bar{W}}=1 / 8$ so $T^{* 1 / \theta}=(8)(1-0.06)^{1 / 8.28}$.

The relative wealth parameter $\zeta$ is chosen to imply a ratio of per-capita consumption of the U.S. to Mexico in steady state that matches the data, which the Penn World Tables indicates is 4.3 in 2000. The parameter $n$ is calibrated to reflect the 74 percent share of the U.S. in the combined population of the two countries. Calibrations of standard preference parameters are taken from the business cycle literature. The labor supply elasticity is set at unity, $\mu=1$, and the curvature parameter is set at $\phi=2$, as is common in the business cycle literature.

The remaining preference parameters are calibrated to reflect the relationship between U.S. and Mexican aggregates. The home bias parameters reflect the share of import expenditures in GDP, $\omega=0.88, \omega^{*}=0.71$. The four U.S. industries classified as offshoring industries in the data set used by Bergin, Feenstra and Hanson (2009) to document the offshoring volatility puzzle (apparel, electrical machinery, computer and electronics, transport equipment) represent $24 \%$ of total U.S. manufacturing, so the offshoring share parameter is calibrated at $\alpha=0.24$. The steady state levels of the additive consumption terms $\left(\bar{G}\right.$ and $\left.\overline{G^{*}}\right)$ are calibrated at values that imply the share of government consumption in total demand is $17 \%$ in steady state equilibrium, which is the share of government purchases in U.S. gross national expenditure data during our sample range.

The mean unit labor requirement in Mexico’s domestic sector $\left(\bar{a}_{F}\right)$ is calibrated to imply a steady state of the model consistent with the assumption above that the Mexican wage is $1 / 8$ that of the U.S. Unit labor requirement shock parameters are estimated from a first-order autoregression on the reciprocal of Solow residuals, computed from monthly manufacturing data from our sample 
range. ${ }^{13}$ Regarding demand shocks, since there is no monthly series available for government consumption, total government spending from IFS is used. Linear trends are removed from the log of each series before fitting it to the first-order autoregressive processes used for all shocks above. See Table 1 for exact values.

\subsection{Numerical Results}

Simulations involve solving the model numerically in its original nonlinear form for 120 periods of random draws of shocks. The first 20 periods are dropped, and the remaining 100 periods are HP filtered and used to compute moments. This process is repeated 1000 times, and we report the average of moments over the replications.

Results for the benchmark case of the model are summarized in column (2) of Table 2; actual moments for Mexico and the U.S. are in column (1), taken from Bergin, Feenstra and Hanson (2009). Although the focus of this study is on the offshoring sector, it is reassuring for our general calibration of shocks that the volatilities for overall manufacturing employment are in the neighborhood of what is observed in the aggregate data, including the fact that overall employment volatility is somewhat higher in the U.S. than in Mexico. Of primary interest is the fact that the calibrated model can easily generate a high degree of volatility in the offshoring sector of Mexico relative to the corresponding U.S. sector, and relative to the overall Mexican economy. The standard deviation of employment for Mexican offshoring, $5.2 \%$, is close to that in the data at $4.4 \%$, and is far greater than the volatility in the U.S. offshoring sector in the simulation, $0.99 \%$, or overall Mexican economy, $0.81 \%$. While the model succeeds in generating the greater volatility in the Mexican offshoring sector, it actually

\footnotetext{
${ }^{13}$ We follow the convention in Glick and Rogoff (1995) of computing Solow residuals by setting the labor share at 0.6 and assuming a constant capital stock. Resulting estimates are almost identical if we assume a labor share of unity, as implied by the production function in the model above.
} 
underestimates the degree of volatility in the U.S offshoring sector, a fact which will be discussed later in the paper. ${ }^{14}$

The model implies a standard deviation of the margin $z^{\prime}$ of $3.7 \%$. The empirical section below will provide an empirical estimate for this volatility of $3.6 \%$, which is remarkably close to the value generated by the benchmark simulation. This result lends support to the way we model the offshoring decision, and the role it plays in generating volatility. In particular, the theoretical model did not include a sunk cost of engaging in offshoring, which could reflect difficulties one might imagine in establishing new offshoring relationships with foreign producers. In practice, offshoring in Mexico seems to exhibit a fairly high degree of fluidity, with arms-length relationships starting and stopping fairly easily. This may be specific to the U.S.-Mexico offshoring relationship. In any case, one might expect such sunk costs to dampen the response in offshoring to transitory shocks, as producers would not pay a significant sunk cost to engage in offshoring that generates benefits for a short-period of time. Given that the standard deviation of the offshoring margin in the benchmark case is close to that in the data, there appears to be little empirical motivation for introducing such an adjustment cost in this model for the case of Mexican offshoring. See the empirical section below for further discussion of volatility in this margin.

The correlations of employment across sectors and across countries all are positive, as is seen also in the U.S.-Mexican data in the table. The positive comovement between the offshoring employment of both countries, $\operatorname{corr}\left(\mathrm{L}_{\mathrm{M}}, \mathrm{L}_{\mathrm{M}}^{*}\right)$, and between U.S. offshoring employment and the offshoring margin, $\operatorname{corr}\left(\mathrm{z}^{\prime}, \mathrm{L}_{\mathrm{M}}\right)$, coincide with the intuition provided in the analytical results section, regarding how demand shocks should generate extra volatility in the Mexican offshoring sector.

\footnotetext{
${ }^{14}$ The model also does not replicate the volatility of the wage-based real exchange rate across countries. The standard deviation of $\log W^{*} / W$ in the simulation is 0.48 ; in data, the standard deviation of $\log s w^{*} / w$, where $s$ is the nominal exchange rate and $w$ and $w^{*}$ are wage indexes from IFS, is 4.22 for our sample range. The failure to explain volatility of real exchange rates of various types is common to our class of models that exclude nominal shocks and nominal rigidities. This property is not a result of endogenous offshoring dampening relative wage volatility, as the volatility of the relative wage is likewise small, 0.87 , when we suspend the $\mathrm{A}(\mathrm{z})$ schedule and hold $z^{\prime}$ fixed.
} 
Columns (3)-(6) of Table 2 report the results when just one of the four shocks is used. These results reveal that the U.S. demand shock is the most important driver of the amplified volatility in the Mexican offshoring sector.

One feature of the data that the benchmark model failed to match was the fact that employment in the U.S. offshoring sector is more volatile than in the overall U.S. economy. Even if this contrast in volatility between offshorable and non-offshorable sectors of the U.S. is much less dramatic than in the Mexican economy, it is a failing, and potentially could reflect the presence of additional shocks specific to the offshoring sector that are shared by both countries. However, another potential explanation is that our specification of Cobb-Douglas preferences implying constant expenditure shares is too simple to capture the relationship among the three classifications of goods. Given that only a fraction of the goods that we classify as offshorable (autos, electronics, etc.) are actually offshored, and the large majority are actually produced entirely at home, one might conjecture they are more similar to the goods we classify as home goods in the model relative to those we classify as foreign goods. As a result, one might conjecture a nested CES consumption aggregator, permitting the elasticity of substitution between home and offshorable goods, $\chi$, to be greater than unity:

$$
C_{t}=\left(\left(\alpha^{\frac{1}{\chi}} C_{M t} \frac{\chi-1}{\chi}+(1-\alpha)^{\frac{1}{\chi}} C_{H t} \frac{\frac{\chi-1}{\chi}}{{ }^{\frac{\chi}{\chi}-1}}\right)^{\omega_{t}} C_{F t}^{1-\omega_{t}} .\right.
$$

We have no compelling way of calibrating such an elasticity, but column (7) reports an experiment where the elasticity assumed in the benchmark simulation is doubled (from a value of 1 to 2), implying that home goods that can be offshored are twice as substitutable with other home goods than with foreign goods. Simulation results reported in column (7) indicate that the volatility of employment in Mexican offshoring and in the overall U.S. and Mexican economies are unaffected by this change in calibration. However, the standard deviation of employment in the U.S. offshoring 
sector increases from $0.99 \%$ to $1.6 \%$, which is much closer to the $2.0 \%$ value observed in data. Recall that a shock raising overall U.S. demand raises relative U.S. wages and hence relative production costs and prices of U.S goods. The price rise is smaller for offshorable goods, because part of the labor and production costs are in Mexico. The higher elasticity implies that more of the demand increase will shift from home goods to offshorable goods, enough that U.S production of goods in that sector rises more than under a unitary elasticity that implies a constant expenditure share for offshorable goods.

Table 3 reports results from a series of robustness checks, with other variations of the model specification. Column (2) confirms the analytical claim above that our main result depends crucially on endogenous movement in the offshoring margin. When the offshoring margin, $z_{t}{ }_{t}$, is held fixed, Mexican employment volatility in the offshoring sector falls sharply, down to a level not much greater than in the U.S. Column (3) shows that Mexican offshoring employment also loses more than half of its volatility if the mean offshoring share is raised from 0.06 to 0.5 . This numerical result coincides with the analytical result that country size in the offshoring sector contributes to higher Mexican volatility.

The four industries we classify as offshorable are not exhaustive, and some degree of offshoring exists in other sectors. To allow for a larger share of goods that are offshorable, column (4) reports results of a model simulation where the share of offshorable goods $(\alpha)$ is doubled from the benchmark calibration (4.8 instead of 2.4). Results are similar to the benchmark calibration, but with some moderation of the Mexican offshoring employment volatility. Next, it is also true that nearly the entirety of goods produced through offshoring by U.S. firms in Mexico is intended for export back to the U.S. for final consumption. The model can be altered to reflect this by specifying a separate expenditure share $\left(\alpha^{*}\right)$ for Mexican preferences in consuming offshorable goods, and 
setting this expenditure share to zero. Column (5) shows that results are nearly identical to the benchmark calibration.

We also consider an alternative specification of the supply shock. The benchmark case holds fixed the $A(z)$ schedule. In that case, supply shocks in the homogeneous goods turn out to have minimal impact on the offshoring margin $z$ ', relative wages, or other endogenous variables. This finding follows from a little-known result in the international macro literature. Consider our model without the offshoring sector, so that it is a two-good Ricardian model with complete asset markets, and assume Cobb-Douglas preferences over the homogeneous goods from each country. Then it turns out that the technology shocks have no impact at all on relative wages. The reason is that a positive supply shock to, say, the home good, will reduce its price on international markets but increase its demand by the same percentage amount, so the implied relative labor demand across countries is unchanged. Relative labor supply is also unchanged due to complete asset markets, so the equilibrium relative wage does not change. ${ }^{15}$ Adding the offshoring sector but with a fixed $A(z)$ schedule leads to nearly the same result.

Column (6) of Table 3 considers the case where the $A(z)$ schedule responds to technology shocks, where $T$ moves in proportion with $a_{H}$ and $T^{*}$ in proportion with $a_{F}^{*}$. While results show an impressive degree of volatility in Mexican offshoring employment, the correlation between Mexican and U.S. employment in the offshoring sector is negative for this experiment, which is clearly counterfactual. Numerical results show that a rise in home supply shifts the $A(z)$ schedule down

\footnotetext{
15 The result that neutral technology shocks have no impact on the relative wage in a two-sector model with large countries and Cobb-Douglas preferences is noted by Krugman (2000), in a model with fixed labor endowments. Using labor choice and complete asset markets, Devereux and Engel (2001) obtain a factor-price equalization result under the assumption that labor enters the utility function linearly. Our assumptions are weaker, since labor enters utility with a power. Combining (16) and (19) we readily obtain $\left(L_{t} / L_{t}^{*}\right)^{\mu}=\left(W_{t} / W_{t}^{*}\right)$, which is the relative labor supply schedule. Relative labor demand in the two-sector Ricardian economy is obtained by combining (14) with Cobb-Douglas preferences , $L_{\mathrm{Ht}} L_{F t}^{*}=a_{\mathrm{Ht}} Y_{\mathrm{Ht}} / a^{*}{ }_{F t} Y_{F t}^{*}=\left(a_{\mathrm{Ht}} / a_{F t}^{*}\right)\left(p_{F t} / p_{H t}\right)$. Then substituting for prices from (15) we have, $L_{H t} / L_{F t}^{*}=\left(a_{H t} / a_{F t}^{*}\left(a_{F t}^{*} W_{t}^{*} / a_{H t} W_{t}\right)=\left(W_{t}^{*} / W_{t}\right)\right.$. In a standard model without an offshoring sector $\left(L_{H, t}=L_{t}, L_{F, t}^{*}=L_{t}^{*}\right.$ ),this proves that both relative labor demand and supply do not depend on the technology shocks, so neither does the equilibrium relative wage.
} 
compared to a given relative wage, inducing a fall in offshoring. This "in-sourcing” behavior implies a negative correlation between employment in the home and foreign offshoring activity, which is counterfactual. Therefore, we conclude that our benchmark specification with supply shocks internationally transmitted in the offshoring sector is a better representation of reality, at least in this model.

Lastly, we check whether the international correlation structure of shocks is important to the result, by conducting a simulation where all off-diagonal elements of $\sigma_{a}, \sigma_{G}, \rho_{a}$, and $\rho_{\mathrm{G}}$ are set to zero. Column (7) shows that simulation results are almost the same as for the benchmark calibration.

\section{Empirical Evidence Regarding the Offshoring Margin}

The theoretical model developed in the preceding section implies that changes in employment by offshoring industries are driven in part by adjustment at the extensive margin. If such a mechanism is operative, we should see entry and exit among the assembly plants in Mexico that produce intermediate goods and services for U.S. industry. There is abundant anecdotal evidence of such plant turnover. During the U.S. economic expansion of the 1990s, the number of maquiladoras in Mexico grew from 1,600 to 3,700. Delphi Automotive Corp., a large U.S. manufacturer of auto parts, expanded its operations in Mexico to include six assembly plants. As U.S. economic growth slowed in 2001 and 2002, over 700 Mexican maquiladoras closed shop. ${ }^{16}$ Delphi shut down two of its Mexican maquiladoras, leaving the other four in operation, thereby reducing employment in the country by $28 \% .{ }^{17}$ Around the same time, Delphi also contracted production in its U.S. plants, reducing domestic employment by a comparatively modest $5 \% .{ }^{18}$ Similar expansions and

\footnotetext{
${ }^{16}$ See “The Decline of the Maquiladora: The Government Isn't Moving to Rescue a Troubled Industry,” Business Week, April 29, 2002.

${ }^{17}$ See Victoria Hirshberg, “Delphi to Consolidate Reynosa, Mexico, Operations,” Texas Knight Ridder/Tribune Business News, July 23, 2004.

${ }^{18}$ See "Delphi Announces Plans to Cut 8,500 Jobs," Associated Press, December 12, 2004. Further, the absolute number of jobs reduced in the U.S. $(3,000)$ was less than the jobs lost overseas $(5,500)$.
} 
contractions in Mexican assembly plants are evident among firms that produce TV sets, cell phones, computer printers, and other manufacturing goods. ${ }^{19}$

More formal evidence of adjustment at the extensive margin comes from examining data on the number of products that Mexico exports to the U.S. We use the Harmonized System (HS) import data for the U.S., at a monthly frequency, and focus on the three largest land border crossings: Laredo, El Paso and San Diego. Table 4 summarizes the average number of HS 10-digit products crossing at each location per month in the four offshoring industries identified above. For example, there are 300 or more types of apparel items being imported at Laredo and San Diego each month, and a smaller number of items in other offshoring industries. We also report the mean number of months that HS products in each industry are exported each year, ranging from 5.8 months for apparel items in El Paso, to 9.0 months for transport equipment in Laredo.

These summary statistics show that there are many 'zeros' in the data, i.e. many instances where an HS product is not exported some month. That fact is also illustrated by Figure 1, which graphs the log number of HS products per month, after deseasonalizing and HP filtering. The standard deviation of these series (reported in Table 2), averaged across industries is 3.6\%. This empirical volatility is very similar to the volatility of 3.7\% found for the benchmark calibration of margin z' in the theoretical model. This indicates that the mechanism used in the theoretical model to explain the employment volatility puzzle requires a degree of movement in the offshoring margin that is modest and plausible.

$<$ Figure 1 about here $>$

\footnotetext{
${ }^{19}$ See Mary Jordan, “Mexican Workers Pay for Success,” Washington Post, June 20, 2002; Elizabeth Malkin, “A Boom along the Border," The New York Times, August 26, 2004; and Diane Lindquist, "Slight Gain in Output Cheers Mexico’s Beleaguered Maquiladora Industry,” San Diego Union-Tribune, March 11, 2004.
} 
Some of the fluctuation in the number of HS products will reflect products that are exported at irregular intervals during the year. But we also expect that some fluctuation is systematic: visually, there appears to be a fall in the number of HS products in 2002, at the time when employment in both Mexico and the U.S. fell substantially. That impression is confirmed by the correlations between the number of HS products and U.S. manufacturing employment reported in Table 3, which are nearly all positive and often exceed 0.25 . Further, the correlation between the offshoring margin and total employment in the offshoring industry summed across countries, $\operatorname{corr}\left(\ln L_{M t}+\ln L_{M t}^{*}, \ln z_{t}^{\prime}\right)$, is positive for all cases, and averages 0.22 across industries and locations. Recall from equations (23) and (24) that this positive correlation (or its corresponding covariance) was shown in the analytical solution above to be necessary and sufficient in our theoretical model to explain the volatility puzzle. This finding lends empirical support for this theoretical condition.

\section{Conclusions}

Global production sharing is responsible for a substantial portion of world trade and is the primary means through which many developing countries engage in international commerce. While the expansion of export assembly operations have lead to impressive rates of employment growth in China, Eastern Europe, Mexico, and elsewhere, the implications of global production sharing for the volatility of economic activity has only recently attracted scholarly attention. In the case of Mexico, the country's offshoring industries experience fluctuations in economic activity that are twice as volatile as the corresponding industries in the U.S. (Bergin, Feenstra, and Hanson, 2009). In this paper, we find that fluctuations in offshoring employment in Mexico result in part from adjustment at the extensive margin, as products enter and exit trade between the two countries.

To account for differences in U.S. and Mexican employment variability, we develop a theoretical model in which heterogeneous firms in a high wage country (the U.S.) are free to enter and exit offshoring relationships with firms in a low wage country (Mexico). Shocks that change 
U.S.-Mexico relative wages induce U.S. firms to alter which products they offshore to Mexico. Adjustment in the offshoring margin is the main mechanism through which U.S. shocks become amplified in Mexico. Stochastic simulations show that the model matches the empirical regularities observed in U.S. offshoring to Mexico. For Mexico, one consequence of economic integration with the U.S. appears to be greater variability in its manufacturing employment.

\section{Acknowledgements}

We thank Thomas Chaney, Fabio Ghironi and seminar participants at the NBER Summer Institute 2007, ASSA 2007 meetings in Chicago, UC San Diego, Carnegie Mellon University, Princeton University, University of Colorado, University of Paris, University of Southern California, the International Monetary Fund and Academia Sinica in Taipei for helpful comments. 


\section{References}

[1] Ambler, S., Cardia, E., and Zimmerman, C., 2002. International transmission of the business cycle in a multi-sectoral model. European Economic Review 46, 273-300.

[2] Amiti, Mary and Wei, Shang-Jin, 2006. Service offshoring and productivity: evidence from the United States. National Bureau of Economic Research Working Paper No. 11926.

[3] Antràs, Pol, and Helpman, Elhanan, 2004. Global sourcing. Journal of Political Economy 112, 552-580.

[4] Bergin, Paul R., Feenstra, Robert C. and Hanson, Gordon H., 2007. Offshoring and volatility. NBER working paper \#13144.

[5] Bergin, Paul R., Feenstra, Robert C. and Hanson, Gordon H., 2009. Offshoring and volatility: evidence from Mexico’s maquiladora industry. American Economic Review 99, 1664-1671.

[6] Berman, Eli, Bound, John, and Machin, Stephen, 1998. Implications of skill-biased technological change: international evidence. The Quarterly Journal of Economics 113(4), 12451279.

[7] Bils, Mark J., 1987. Real wages over the business cycle: evidence from panel data. Journal of Political Economy 93(4), 666-689.

[8] Botero, J., Djankov, S., La Porta, R., López de Silanes, F., and Schleifer, A., 2004. The regulation of labor. Quarterly Journal of Economics 119 (4), 1339-1382.

[9] Burstein, Ariel, Kurz, Johann, and Tesar, Linda, 2008. Trade, production sharing, and the international transmission of business cycles. Journal of Monetary Economics 55 (4), 775-795.

[10] Chari, V.V., Kehoe, Patrick J., and McGrattan, Ellen R., 2002. Can sticky price models generate volatile and persistent real exchange rates? Review of Economic Studies 69, 533-563.

[11] Comin, Diego, Loayza, Norman, Pasha, Farooq, and Serven, Luis, 2009. Medium term business cycles in developing countries. NBER Working Paper 15428.

[12] Devereux, Michael B., and Engel, Charles, 2001. The optimal choice of exchange-rate regime: price-setting rules and internationalized production,” in Magnus Blomstrom and Linda Goldberg, eds. Topics in Empirical International Economics: Festschrift in Honor of Robert Lipsey, NBER and Univ. of Chicago, 163-189.

[13] Dornbusch, Rudiger, Fischer, Stanley, and Samuelson, Paul A., 1977. Comparative advantage, trade, and payments in a Ricardian model with a continuum of goods. American Economic Review 67(5), 823-839.

[14] Eaton, Jonathan and Kortum, Samuel, 2002. Technology, geography and trade. Econometrica 70(5), 1741-1779. 
[15] Ebenstein, Avraham, Harrison, Ann, McMillan, Margaret, and Phillips, Shannon, 2010. Estimating the impact of trade and offshoring on American workers using the current population surveys. Mimeo, UC Berkeley.

[16] Feenstra, Robert C., 2009. Offshoring in the Global Economy. Cambridge, MA: MIT Press.

[17] Hanson, Gordon H., 1999. The impact of outsourcing and high-technology capital on wages: estimates for the United States, 1979-1990. The Quarterly Journal of Economics 114 (3), 907-940.

[18] Glick, Reuven and Rogoff, Kenneth, 1995. Global versus country-specific productivity shocks and the current account. Journal of Monetary Economics 35(1), 159-192.

[19] Grossman, Gene and Rossi-Hansberg, Esteban, 2008. A simple theory of offshoring. American Economic Review 98 (5), 1978-1997.

[20] Huang, Kevin X.D., Liu, Zheng, and Phaneuf, Louis, 2004. Why does the cyclical behavior of real wages change over time? American Economic Review 94 (4), 836-856.

[21] Hummels, David, Ishii, Jun, and Yi, Kei-Mu, 2001. The nature and growth of vertical specialization in world trade. Journal of International Economics 54, 75-96.

[22] Kose, M. Ayhan and Yi, Kei-Mu, 2001. International trade and business cycles: is vertical specialization the missing link? American Economic Review 91, 371-375.

[23] Kose, M. Ayhan and Yi, Kei-Mu, 2006. Can the standard real business cycle model explain the relation between trade and comovement? Journal of International Economics 68(2), 267-295.

[24] Krugman, Paul. R., 2000. Technology, trade and factor prices. Journal of International Economics 50 (1), 51-71.

[25] Zlate, Andrei, 2008. Offshore production and business cycle dynamics with heterogeneous firms. Boston College Mimeo. 


\section{Appendix}

\section{Deriving labor demands in the offshoring sector}

Labor demand in the multinational sector at home is obtained by integrating over the variable labor input requirement $a_{M t}(z) y_{M t}(z)$ for those products $z \in\left[z^{\prime}, 1\right]$ :

$$
L_{t}=\int_{z_{t}^{\prime}}^{1} a_{M t}(z) y_{M t}(z) d z
$$

Multiply the labor input requirement in the integral by the wage $W_{t}$ to obtain the expenditure $\left[C_{M t}+C_{M t}^{*}(1-n) / n\right]$ on each variety. So the expression inside the integral of (A1) equals $\left[C_{M t}+C_{M t}^{*}(1-n) / n\right] W_{t}$, which is integrated over $z \in\left[z_{t}^{\prime}, 1\right]$ to yield (5).

For foreign labor demand we integrate the variable labor input requirement $a_{M t}^{*}(z) y_{t}^{*}(z)$ for $z \in\left[0, z_{t}^{\prime}\right]:$

$$
L_{t}^{*}=\int_{0}^{z_{t}^{\prime}} a_{M t}^{*}(z) y_{t}^{*}(z) d z
$$

Multiplying the labor input requirement $a^{*} y_{t}^{*}(z)$ by the wage $W_{t}^{*}$, we again obtain the expenditure $\left[C_{M t}+C_{M t}^{*}(1-n) / n\right]$ on each variety. So the expression inside the integral of (A2) equals $\left[C_{M t}+C_{M t}^{*}(1-n) / n\right] / W_{t}^{*}$, which is integrated over $z \in\left[0, z^{\prime}{ }_{t}\right]$ to yield (6).

\section{Derivation of price index for multinational goods sector:}

$$
\begin{aligned}
& \ln P_{M t}=\int_{0}^{z_{t}^{\prime}} \ln \left(W_{t}^{*} a_{M, t}^{*}\left(z_{t}\right)\right) d z+\int_{z_{t}^{\prime}}^{1} \ln \left(W_{t} a_{M, t}\left(z_{t}\right)\right) d z \\
& =\int_{0}^{z_{t}^{\prime}} \ln \left(W_{t}^{*}\left(\frac{T^{*}}{1-z}\right)^{\frac{1}{\theta}}\right) d z+\int_{z_{t}^{\prime}}^{1} \ln \left(W_{t}\left(\frac{T}{z}\right)^{\frac{1}{\theta}}\right) d z \\
& =\int_{0}^{z_{t}^{\prime}} \ln \left(W_{t}^{*} T^{* \frac{1}{\theta}}\right) d z-\frac{1}{\theta} \int_{0}^{z_{t}^{\prime}} \ln (1-z) d z+\int_{z_{t}^{\prime}}^{1} \ln \left(W_{t} T^{\frac{1}{\theta}}\right) d z-\frac{1}{\theta} \int_{z_{t}^{\prime}}^{1} \ln (z) d z
\end{aligned}
$$




$$
\begin{aligned}
& =\left.\ln \left(W_{t}^{*} T^{* \frac{1}{\theta}}\right) z\right|_{0} ^{z_{t}^{\prime}}+\left.\frac{1}{\theta}((1-z) \ln (1-z)-(1-z))\right|_{0} ^{z_{t}^{\prime}}+\left.\ln \left(W_{t} T^{\frac{1}{\theta}}\right) z\right|_{z_{t}^{\prime}} ^{1}-\left.\frac{1}{\theta}(z \ln z-z)\right|_{z_{t}^{\prime}} ^{1} \\
& =\ln \left(W_{t}^{*} T^{* \frac{1}{\theta}}\right) z_{t}^{\prime}+\ln \left(W_{t} T^{\frac{1}{\theta}}\right)\left(1-z_{t}^{\prime}\right)+\frac{1}{\theta}\left(\left(1-z_{t}^{\prime}\right) \ln \left(1-z_{t}^{\prime}\right)\right)-\frac{1}{\theta}\left(z_{t}^{\prime} \ln _{t} z_{t}^{\prime}\right)+\frac{2}{\theta} z_{t}^{\prime}+\frac{1}{\theta}
\end{aligned}
$$

\section{Deriving comparative statics for offshoring margin:}

$$
\begin{aligned}
& \text { define } F \equiv\left(\frac{z}{1-z}\right)^{\frac{1}{\theta}\left(1+\frac{1}{\mu}\right)}\left(\frac{\alpha \omega z_{t}^{\prime}+(1-\omega)}{\omega\left(1-\alpha z_{t}^{\prime}\right)}\right)-(\zeta)^{\frac{1}{\mu}}\left(\frac{T}{T^{*}}\right)^{\frac{1}{\theta}\left(1+\frac{1}{\mu}\right)}\left(\frac{1-n}{n}\right) \\
& \frac{\partial F}{\partial z}=\left(\frac{z}{1-z}\right)^{\frac{1}{\theta}\left(1+\frac{1}{\mu}\right)}\left(\frac{\omega\left(1-\alpha z_{t}^{\prime}\right) \alpha \omega+\left(\alpha \omega z_{t}^{\prime}+(1-\omega)\right) \alpha \omega}{\left(\omega\left(1-\alpha z_{t}^{\prime}\right)\right)^{2}}\right)+\left(\frac{\alpha \omega z_{t}^{\prime}+(1-\omega)}{\omega\left(1-\alpha z_{t}^{\prime}\right)}\right)\left(\frac{1}{\theta}\left(1+\frac{1}{\mu}\right)\right)\left(\frac{z}{1-z}\right)^{\frac{1}{\theta}\left(1+\frac{1}{\mu}\right)-1}\left(\frac{1}{(1-z)^{2}}\right)>0
\end{aligned}
$$

So we know $\frac{\partial z}{\partial \omega}=-\frac{\partial F}{\partial \omega} / \frac{\partial F}{\partial z}>0$.

$\frac{\partial F}{\partial \omega}=\left(\frac{z}{1-z}\right)^{\frac{1}{\theta}\left(1+\frac{1}{\mu}\right)}\left(\frac{\omega\left(1-\alpha z_{t}^{\prime}\right)\left(\alpha z_{t}^{\prime}-1\right)-\left(\alpha \omega z_{t}^{\prime}+(1-\omega)\right)\left(1-\alpha z_{t}^{\prime}\right)}{\left(\omega\left(1-\alpha z_{t}^{\prime}\right)\right)^{2}}\right)<0$

\section{Deriving necessary and sufficient condition (22-23):}

Rearrange (21) as follows

$$
\frac{d \ln L_{M t}}{d \omega_{t}}=\frac{d \ln L_{M t}^{*}}{d \omega_{t}}-\left(1+\frac{1}{\theta}\right) \frac{1}{\left(1-Z_{t}^{\prime}\right)} \frac{d \ln z_{t}^{\prime}}{d \omega_{t}}
$$

and use this to write:

$$
\operatorname{var}\left(\ln L_{M t}\right)=\operatorname{var}\left(\ln L_{M t}^{*}\right)+\left(1+\frac{1}{\theta}\right)^{2}\left(\frac{1}{1-\overline{Z^{\prime}}}\right)^{2} \operatorname{var}\left(\ln Z_{t}^{\prime}\right)-2\left(1+\frac{1}{\theta}\right)\left(\frac{1}{1-\overline{Z^{\prime}}}\right) \operatorname{cov}\left(\ln L_{M t}^{*}, \ln z_{t}^{\prime}\right)
$$

Sum this with (22) to write (23). 
Table 1. Calibration of model Parameters

\section{$\underline{\text { Preferences }}$}

$\omega \quad$ home bias in U.S. $\quad 0.88$

$\omega^{*} \quad$ home bias in Mexico 0.71

$\alpha \quad$ offshoring expenditure share $\quad 0.24$

$\mu \quad$ labor supply elasticity $\quad 1$

$\phi \quad$ risk aversion 2

$n \quad$ relative size of U.S. $\quad 0.74$

$\zeta \quad$ relative wealth of U.S. 31.3

$\bar{G} \quad$ U.S. mean government demand $\quad 0.164$

$\overline{G^{*}} \quad$ Mexican mean government demand $\quad 0.00382$

$\underline{\text { Technology }}$

$\overline{a_{H}} \quad$ US steady state unit cost $\quad 1$

$\overline{a_{F}^{*}} \quad$ Mexican steady state unit cost $\quad 3.15$

$\bar{Z}^{\prime} \quad$ offshoring margin $\quad 0.06$

$\theta \quad$ curvature of distribution $\quad 8.28$

$T^{1 / \theta} \quad$ US offshoring technology term $\quad 0.71$

$T^{* 1 / \theta} \quad$ Mexican offshoring technology term $\quad 7.94$

$\underline{\text { Shock processes }}$

$$
\begin{array}{ll}
\sigma_{a}^{2}=\left[\begin{array}{cc}
6.42 \times 10^{-5} & -4.67 \times 10^{-6} \\
-4.67 \times 10^{-6} & 1.87 \times 10^{-4}
\end{array}\right] & \rho_{a}=\left[\begin{array}{cc}
0.931 & -4.02 e^{-2} \\
7.38 e-3 & 0.961
\end{array}\right] \\
\sigma_{G}^{2}=\left[\begin{array}{cc}
7.68 \times 10^{-3} & 4.02 \times 10^{-3} \\
4.02 \times 10^{-3} & 2.36 \times 10^{-2}
\end{array}\right] & \rho_{G}=\left[\begin{array}{cc}
-0.0549 & 0.379 \\
-0.368 & 0.424
\end{array}\right]
\end{array}
$$


Table 2. Model Simulation for Production Worker Employment

\begin{tabular}{lccccccc}
\hline & $\begin{array}{c}(1) \\
\text { Mexican } \\
\text { or U.S. } \\
\text { Data }\end{array}$ & $\begin{array}{c}\text { Bench- } \\
\text { mark } \\
\text { Model }\end{array}$ & $\begin{array}{c}\text { U.S. } \\
\text { Demand } \\
\text { Shock }\end{array}$ & $\begin{array}{c}\text { Mexico } \\
\text { Demand } \\
\text { Shock }\end{array}$ & $\begin{array}{c}\text { U.S. } \\
\text { Supply } \\
\text { Shock }\end{array}$ & $\begin{array}{c}\text { Mexico } \\
\text { Supply } \\
\text { Shock }\end{array}$ & $\begin{array}{c}\text { High } \\
\text { Elasticity } \\
(\chi=2)\end{array}$ \\
\hline Std. devs. (\%): & & & & & & & \\
$\sigma\left(L^{*}{ }_{M}\right)$ & 4.44 & 5.18 & 4.66 & 2.17 & 0.97 & 0.03 & 5.05 \\
$\sigma\left(L_{M}\right)$ & 2.04 & 0.99 & 0.65 & 0.12 & 0.40 & 0.31 & 1.63 \\
$\sigma\left(L^{*}\right)$ & 0.89 & 0.81 & 0.38 & 0.28 & 0.37 & 0.33 & 0.81 \\
$\sigma(L)$ & 1.15 & 1.13 & 0.82 & 0.03 & 0.43 & 0.30 & 1.14 \\
$\sigma\left(L^{*}{ }_{M}\right) / \sigma\left(L_{M}\right)$ & 2.21 & 5.26 & 7.17 & 17.70 & 2.40 & 0.09 & 3.15 \\
$\sigma\left(L^{*}\right) / \sigma(L)$ & 0.77 & 0.72 & 0.47 & 9.65 & 0.86 & 1.10 & 0.71 \\
\hline Correlations: & & & & & & & \\
$\operatorname{corr}\left(L^{*}{ }_{M}, L_{M}\right)$ & 0.51 & 0.80 & 1.00 & -1.00 & 1.00 & 0.99 & 0.63 \\
$\operatorname{corr}\left(L^{*}, L\right)$ & 0.78 & 0.93 & 1.00 & 1.00 & 1.00 & 1.00 & 0.94 \\
$\operatorname{corr}\left(L^{*}{ }_{M}, L^{*}\right)$ & 0.64 & 0.61 & 1.00 & -1.00 & 1.00 & 0.99 & 0.57 \\
$\operatorname{corr}\left(L_{M}, L\right)$ & 0.76 & 0.99 & 1.00 & 1.00 & 1.00 & 1.00 & 0.34 \\
\hline Margins $(\%):$ & & & & & & & \\
$\sigma\left(\mathrm{z}^{\prime}\right)$ & 3.61 & 3.71 & 3.36 & 1.93 & 0.48 & 0.23 & 3.54 \\
$\operatorname{corr}\left(\mathrm{z}^{\prime}, L^{*}{ }_{M}+L_{M}\right)$ & 0.22 & 0.97 & 1.00 & 1.00 & 1.00 & -1.00 & 0.87 \\
& & & & & & & \\
\hline
\end{tabular}

Notes:

All variables are in natural logs. 
Table 3. Robustness Checks in Model Simulations: Production Worker Employment

\begin{tabular}{|c|c|c|c|c|c|c|c|}
\hline & $\begin{array}{c}(1) \\
\text { Bench- } \\
\text { mark } \\
\text { Model }\end{array}$ & $\begin{array}{c}(2) \\
\text { Fixed } \\
\text { z' }^{\prime}\end{array}$ & $\begin{array}{c}(3) \\
\overline{Z^{\prime}}=0.5\end{array}$ & $\begin{array}{c}(4) \\
\text { High } \\
\text { M share } \\
(\alpha=4.8)\end{array}$ & $\begin{array}{c}(5) \\
\text { Low Mex } \\
\text { M share } \\
\left(\alpha^{*}=0\right)\end{array}$ & $\begin{array}{c}\text { (6) } \\
\text { Altern. } \\
\text { supply } \\
\text { Shocks } \\
\end{array}$ & $\begin{array}{c}(7) \\
\text { Uncor. } \\
\text { Shocks }\end{array}$ \\
\hline \multicolumn{8}{|l|}{ Std. devs. (\%): } \\
\hline$\sigma\left(L_{M}^{*}\right)$ & 5.18 & 1.72 & 2.01 & 4.11 & 5.20 & 15.83 & 5.24 \\
\hline$\sigma\left(L_{M}\right)$ & 0.99 & 1.14 & 0.65 & 1.11 & 1.00 & 1.22 & 0.84 \\
\hline$\sigma\left(L^{*}\right)$ & 0.81 & 0.74 & 0.96 & 0.94 & 0.81 & 1.09 & 0.68 \\
\hline$\sigma(L)$ & 1.13 & 1.15 & 1.11 & 1.18 & 1.13 & 1.10 & 0.97 \\
\hline$\sigma\left(L^{*}{ }_{M}\right) / \sigma\left(L_{M}\right)$ & 5.26 & 1.51 & 3.10 & 3.72 & 5.21 & 13.22 & 6.31 \\
\hline$\sigma\left(L^{*}\right) / \sigma(L)$ & 0.72 & 0.65 & 0.87 & 0.79 & 0.71 & 1.00 & 0.70 \\
\hline \multicolumn{8}{|l|}{ Correlations: } \\
\hline$\overline{\operatorname{Corr}\left(L^{*}{ }_{M}, L_{M}\right)}$ & 0.80 & 0.97 & 0.74 & 0.85 & 0.80 & -0.32 & 0.73 \\
\hline $\operatorname{corr}\left(L^{*}, L\right)$ & 0.93 & 0.83 & 1.00 & 0.97 & 0.93 & 0.70 & 0.87 \\
\hline $\operatorname{corr}\left(L^{*}{ }_{M}, L^{*}\right)$ & 0.61 & 0.67 & 0.94 & 0.74 & 0.62 & 0.79 & 0.44 \\
\hline $\operatorname{corr}\left(L_{M}, L\right)$ & 0.99 & 1.00 & 0.88 & 1.00 & 0.99 & 0.75 & 0.99 \\
\hline \multicolumn{8}{|l|}{ Margins (\%): } \\
\hline$\sigma\left(z^{\prime}\right)$ & 3.71 & 0.00 & 0.71 & 2.70 & 3.72 & 15.78 & 3.92 \\
\hline $\begin{array}{l}\text { corr } \\
\left(z^{\prime}, L^{*}{ }_{M}+L_{M}\right)\end{array}$ & 0.97 & 0.00 & 0.90 & 0.96 & 0.97 & 0.98 & 0.98 \\
\hline
\end{tabular}

Notes:

All variables are in natural logs. 
Table 4: U.S. Harmonized System Imports from Mexico, 1996-2006

\begin{tabular}{|c|c|c|c|c|}
\hline & Apparel & $\begin{array}{c}\text { Electrical } \\
\text { Machinery }\end{array}$ & $\begin{array}{c}\text { Computer \& } \\
\text { Electronics } \\
\end{array}$ & $\begin{array}{c}\text { Transport } \\
\text { Equipment }\end{array}$ \\
\hline \multicolumn{5}{|l|}{ Laredo, TX } \\
\hline$\overline{\text { Mean Number of HS Products }}$ & 384.0 & 219.2 & 258.6 & 140.5 \\
\hline \multicolumn{5}{|l|}{ Mean Number of Months a HS Product is } \\
\hline Imported Per Year ${ }^{\mathrm{a}}$ & 6.9 & 8.9 & 7.5 & 9.0 \\
\hline Std. Dev. Log Number of HS Products ${ }^{b}$ & 2.64 & 2.14 & 3.10 & 2.94 \\
\hline $\begin{array}{l}\text { Correlation of Number of HS Products } \\
\text { and U.S. Manufacturing Employment }{ }^{\mathrm{c}}\end{array}$ & 0.28 & 0.32 & 0.07 & 0.31 \\
\hline \multicolumn{5}{|l|}{$\begin{array}{l}\text { Correlation of Number of HS Products } \\
\text { and sum of U.S. and Mexican }\end{array}$} \\
\hline Employment in the industry & 0.365 & 0.406 & 0.052 & 0.078 \\
\hline \multicolumn{5}{|l|}{ El Paso, TX } \\
\hline Mean Number of HS Products & 162.6 & 137.0 & 208.3 & 53.4 \\
\hline \multicolumn{5}{|l|}{ Mean Number of Months a HS Product is } \\
\hline Imported Per Year ${ }^{\mathrm{a}}$ & 5.8 & 8.9 & 7.8 & 7.8 \\
\hline Std. Dev. Log Number of HS Products ${ }^{b}$ & 4.99 & 2.43 & 2.60 & 5.66 \\
\hline $\begin{array}{l}\text { Correlation of Number of HS Products } \\
\text { and U.S. Manufacturing Employment }{ }^{\mathrm{c}}\end{array}$ & 0.05 & 0.04 & 0.12 & 0.30 \\
\hline \multicolumn{5}{|l|}{$\begin{array}{l}\text { Correlation of Number of HS Products } \\
\text { and sum of U.S. and Mexican }\end{array}$} \\
\hline Employment in the industry & 0.122 & 0.130 & 0.067 & 0.435 \\
\hline \multicolumn{5}{|l|}{ San Diego, CA } \\
\hline$\overline{\text { Mean Number of HS Products }}$ & 299.8 & 129.6 & 237.0 & 53.2 \\
\hline \multicolumn{5}{|l|}{ Mean Number of Months a HS Product is } \\
\hline Imported Per Year ${ }^{\mathrm{a}}$ & 6.3 & 8.3 & 7.5 & 7.0 \\
\hline Std. Dev. Log Number of HS Products ${ }^{b}$ & 3.38 & 3.86 & 3.39 & 6.18 \\
\hline $\begin{array}{l}\text { Correlation of Number of HS Products } \\
\text { and U.S. Manufacturing Employment }{ }^{\mathrm{c}}\end{array}$ & -0.01 & 0.28 & 0.25 & 0.12 \\
\hline \multicolumn{5}{|l|}{$\begin{array}{l}\text { Correlation of Number of HS Products } \\
\text { and sum of U.S. and Mexican }\end{array}$} \\
\hline Employment in the industry & 0.067 & 0.420 & 0.225 & 0.305 \\
\hline
\end{tabular}

\section{Notes:}

a. Averaged over HS products and over the years 1996-2006.

b. The log number of HS products has been deseasonalized and HP filtered, and the standard deviation is multiplied by 100 .

c. The number of HS products and U.S, manufacturing employment are in logs, and are deseasonalized and HP filtered.

\section{Source:}

Bureau of the Census, 1996-2006, U.S. Exports and Imports of Merchandise on CD-ROM [machinereadable data file], Washington, D.C. 
Figure 1: The Number of HS Products Over Years

(Average over 3 ports; Log values, seasonally adjusted, HP filtered)
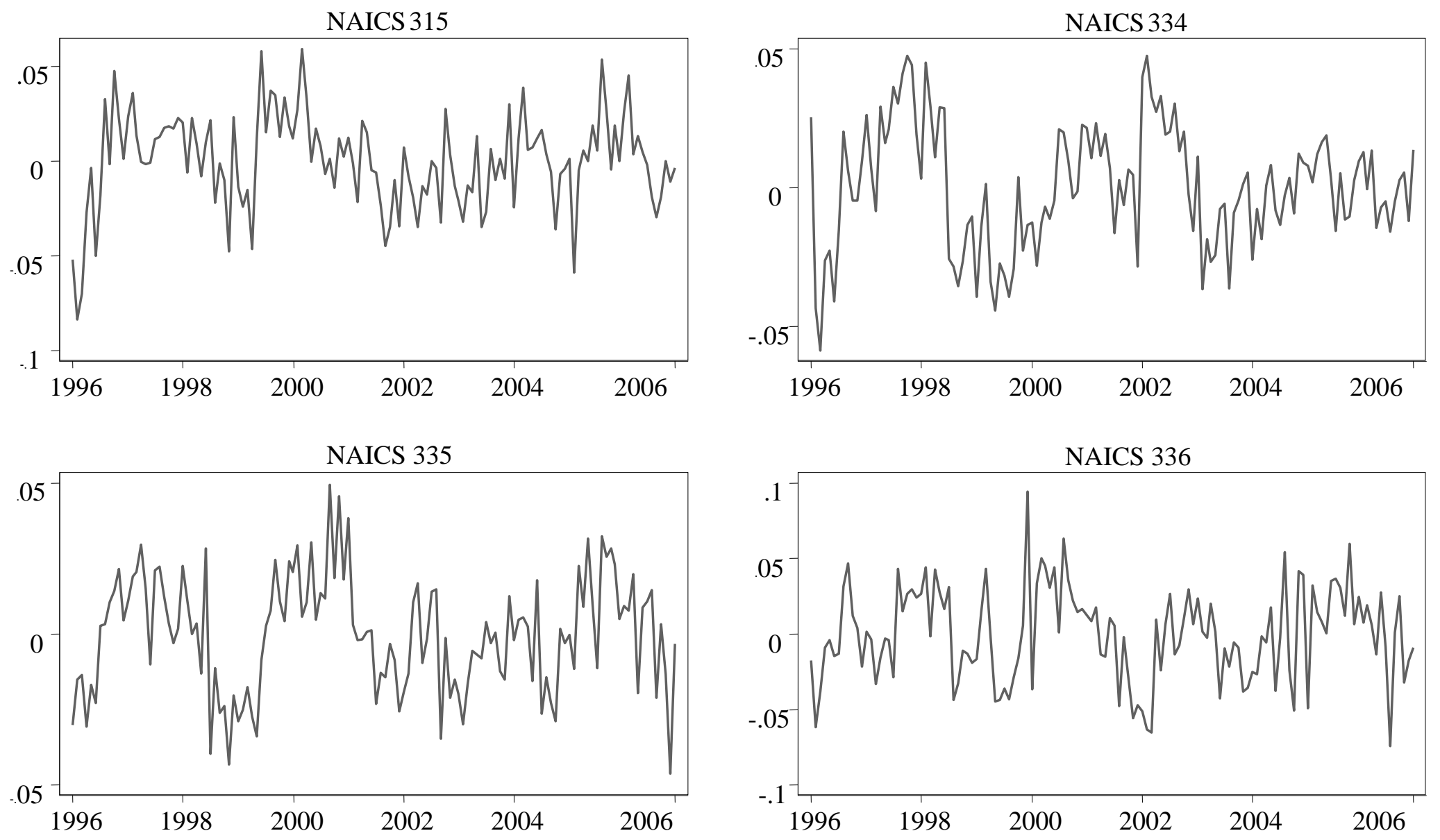